\title{
Influence of Climatic Conditions \\ on the Traditional Economy \\ of the Indigenous Small-Numbered Peoples Living \\ in the Evenkiyskiy Municipal District \\ (Krasnoyarsk Territory)
}

\author{
Maria A. Kolesnik, Natalia M. Libakova*, \\ Ekaterina A. Sertakova and Natalia A. Sergeeva \\ Siberian Federal University \\ 79 Svobodny, Krasnoyarsk, 660041, Russia
}

Received 14.07.2017, received in revised form 10.08.2017, accepted 22.08.2017

\begin{abstract}
At present the climate problem is one of the most relevant and discussed in various contexts. The article raises a problem of the interconnection between climatic conditions and the implementation of traditional forms of the economy management by the indigenous inhabitants of the Evenkiysky Municipal District of the Krasnoyarsk Territory. Based on the results of the field research, interviewing of experts and application of the Delphi survey method, the authors make conclusions about the current state of the traditional economy of the indigenous small-numbered peoples of the North of the Krasnoyarsk Territory and the impact of climatic conditions on it, and provide forecasts on the prospects for the development of traditional forms of the economy management (reindeer breeding, hunting, fishing, wild plant gathering) taking into account the influence of climatic conditions and their dynamics.
\end{abstract}

Keywords: traditional forms of economy management, indigenous small-numbered peoples, climatic conditions, Evenkiysky Municipal District, Krasnoyarsk Territory.

The study was funded by the Russian Foundation for Basic Research, Government of the Krasnoyarsk Territory, Krasnoyarsk Region Science and Technology Support Fund to the research project No. 17-16-24601.

DOI: 10.17516/1997-1370-0139.

Research area: culturology.

\section{Introduction}

In the context of active development of the Northern territories, in particular in the context of industrial development and development of natural resources, the issues of ecology and climate changes due to the anthropogenic impact are among the most discussed and ambiguous ones. The climate issue is a subject of discussions both in the scientific community and in the political sphere. It is difficult to overestimate the importance of natural conditions in general, and climatic conditions in

(C) Siberian Federal University. All rights reserved

* Corresponding author E-mail address: trognonulia@gmail.com 
particular, for the emergence and development of traditional forms of economic activity. Modern representatives of the indigenous smallnumbered peoples of the Evenkiysky Municipal District, like their ancestors, are engaged in reindeer herding, fishing, hunting, gathering of wild plants. Certainly, the discussed changes in climatic conditions can make a difference for the development of the traditional economy of the inhabitants of the North of the Krasnoyarsk Territory.

Existing views on the impact of human activities on climate changes are divided. On the one hand, there are supporters of the position that human activity is not as significant as the natural processes occurring on the planet and the observed climate changes are not the result of anthropogenic interference. On the other hand, the opposite view, according to which the active human activity associated with the development of natural resources, industrial development, urbanization, is the determining factor provoking irreversible consequences, such as the global climate change.

For example, part of scientists whose works are published in foreign publications call the anthropogenic factor one of the key factors in changes in climatic conditions that we are currently observing. Most researchers are trying to find adequate ways to predict future climate changes and their consequences. In particular, R.H. Moss with co-authors (2010) state that the consequences of changes affect not only in the response of ecosystems to them, but also in how it influences all areas of people's lives from economics and politics to living conditions. In this regard, the article notes the great role of interaction between the natural sciences and the Humanities in forecasting the future and creating plausible scenarios of climate changes.

Russian scientists also pay attention to the anthropogenic factor in climate change, such as
V.P. Meleshko (2004), Iu.A. Israel' (2001), A.A. Tishkov (2011).

In his monograph (2012) V. Loginov examines not only the facts that affect climate changes and that are the result of human activity, but also those facts that do not fit into this concept. The author justifies the need to analyze climate change research from various points of view by the fact that there is currently a significant increase in scepticism of the population of different countries in relation to climate issues. Thus, the researcher is trying to take into account both the anthropogenic factor and natural changes in modelling of forecasts for the future in equal measure. V.M. Kotliakov (2001) also points to the dual nature of climate changes: the anthropogenic factor cannot be denied, but studies in climatology show that there are natural nonlinear processes that also have a very significant effect on the climate. K.Ia. Kondrat'ev (2002) holds the same view: "Until very recently, the concept of "climate change" has been defined as an anthropogenically conditioned climate change, although one of the main unresolved problems is the lack of convincing quantitative estimates of the contribution of anthropogenic factors to the formation of global climate (no one doubts, however, that there are anthropogenic impacts on the climate)".

The report of the Intergovernmental Panel on Climate Change (IPCC) (2014) identifies the problems associated with climate changes that have already occurred and those that are predicted as possible consequences for human health and ecosystems, how it has affected and may affect the human activity.

Scientists working in countries that are sensitive to the problems associated with life of the indigenous peoples in the Northern Arctic Region focus their research on how the inhabitants of these territories can adapt to changes that change the habitual climatic conditions of life. Thus, 
J.D. Ford, B. Smit, J. Wandel (2006) describe the experience of Inuit inhabitants - the indigenous peoples of the Canadian Arctic Region who in many ways demonstrated their ability to adapt to the new conditions created by climate changes, which is due to the traditional knowledge of these peoples, strong social ties, their ability to adapt to changes in hunting seasons, as well as due to the penetration of certain modern technologies into their lives and the implementation of economic support from the government. However, the transformations that have occurred in their traditional way of life have also affected the fact that, in some aspects, they have lost their skills of adaptation to the surrounding conditions.

Interestingly, many researchers in Canada believe that traditional knowledge of the indigenous peoples can significantly and effectively supplement scientific approaches in the study of climate changes (Berkes, Jolly, 2002; Riedlinger, Berkes, 2001; Pearce et al., 2015). One of the conditions for the stable development of the indigenous ethnoses is the traditional activities and cultural ties, the integrity of which increases the level of possibilities for adaptation to conditions in a changing world. Also Riedlinger D., Berkes F. (2001) emphasize that the knowledge of the indigenous inhabitants of the North greatly expand the views of scientists about the history of climate changes, and also contribute to more precise formulations of hypotheses and research tasks.

Other Canadian scientists note that the negative effects of climate changes on the livelihoods of the indigenous peoples in Northern Canada have already been documented and that it is an important problem that representatives of the indigenous peoples, scientists and local authorities work together to solve (Furgal, Seguin, 2006).

Some scientists identify a particular problem of how climate change affects the culture of society (Adger et al., 2013). In this respect, it is again possible to emphasize the importance of interdisciplinary studies of climate-related problems, including cultural ones, since it is noted that all changes in the surrounding natural world are reflected in the world of culture.

A group of the authors of the monograph "The Arctic Space of Russia in the $21^{\text {st }}$ Century" (2016) also draws attention to the climate problems in this territorial zone. Along with the fact that the authors note the need for constant monitoring of climate and ecology in the Arctic Region, practically no attention is paid to the problems arising in the line of this approach, arising among the indigenous population and only the issues related to the country's scale as a whole are discussed in the economic development strategies.

V.M. Katsov, B.N. Porfir'ev (2012) draw attention to the fact that climate changes must inevitably have an impact on the economy of the region in the near future. In particular, the authors say that warming affects the reduction of hunting time, but, at the same time, contributes to the development of fisheries. The traditional economy and the way of life of the population must inevitably undergo changes, which threatens its survival.

N.A. Lopulenko (2009) notes that in Russia there is a problem of insufficient attention to the problems of ethno-cultural consequences associated with the global climate changes. The article examines the consequences of these changes, including their impact on the traditional economic activities of the indigenous peoples, and as a result, how this affects the level of people's health: "The divergence of the indigenous people in some regions from traditional food and farming methods and the transition to non-traditional (more western) food and sedentary lifestyle leads to an increase in the incidence of cardiovascular 
diseases, the development of diabetes, caries and obesity" (2009).

To date, quite a lot of research works have been devoted to the traditional economy of the indigenous small-numbered peoples of the North who live in the territory of the Krasnoyarsk Territory. For example, A.A. Medvedkov (2012) raises a question that it is necessary to take a series of measures connected with the adaptation of the traditional economy of the Kets who live in the territory of Evenkia to rapidly changing climate conditions. The close interconnection of the traditional economy, ethnic culture and climate changes has been studied by T.M. Krasovskaya (2006), K.B. Blokov, A.N. Iamskaia (2002), M.I. Bukova (2016), V.I. Kirko (Kirko et al., 2012), Kirko, 2015, Kistova, Kistova and Sevruzhenko (2016), Koptseva and Kolesnik (2015), N.G. Shishatskii (2012) and some other researchers.

Also, scientists point out a tendency associated with the refusal of the indigenous peoples of the North to conduct traditional farming and the desire to move to other regions for permanent residence. At the same time, they cannot adapt to new conditions, which threatens their existence in the future, since their ethnic identity is getting eroded and cultural ties are getting lost (Kirko, Zakharova, 2013; Kirko, Keush, 2010; Zamaraeva, 2014; Seredkina, 2014, Seredkina, 2016).

A comprehensive study of the life of the indigenous small-numbered peoples of the North of the Krasnoyarsk Territory has been conducted for several years by scientists of the Chair for Cultural Studies of the Siberian Federal University. The result of these studies was work that highlights the current situation in the region, including the problems associated with the adaptation of the indigenous peoples to those changes that affect all areas of their livelihoods (Amosov et al., 2012; Kirko et al., 2010). A subject of preserving the traditional culture of the indigenous peoples of the North has been studied in a number of articles by N.P. Koptseva (2013, 2015), N.N. Pimenova (2012, 2014, 2016), K.V. Reznikova (2015a, 2015b), N.M. Libakova, E.A. Sertakova (2014, 2016), V.S. Luzan (2016).

\section{Methods}

The purpose of this study is to analyze the influence of climatic conditions on the traditional economy of the indigenous small-numbered peoples living in the Evenkiysky Municipal District of the Krasnoyarsk Territory. To achieve this purpose, the actual materials collected during the comprehensive field research in the territory of the Evenks' settlement, which has been conducted since 2010 to the present by scientists and students of the Chair for Cultural Studies of the Siberian Federal University with the participation of scientists of the Krasnoyarsk State Agrarian University and the Krasnoyarsk State Pedagogical University named after. V.P. Astaf'ev.

A synthesis of the results obtained through in-depth interviewing of specialists in the field of protection and preservation of the natural habitat of the indigenous peoples, experts in the field of traditional economy, as well as information obtained in interviews with practitioners representatives of the indigenous small-numbered peoples engaged in reindeer herding (the main traditional occupation of the indigenous peoples in Evenkia) made it possible to draw conclusions about the current state of affairs in the sphere of the traditional economy. Also it helped to understand the influence of climatic conditions on the traditional forms of economic management.

The materials obtained through the use of the Delphi survey method formed the basis for the forecasts concerning the development of the traditional economy of the indigenous peoples of Evenkia in the context of understanding the influence of climatic conditions. The Delphi 
survey is effective for solving the problem of systematizing the opinions of experts in a certain sphere. For this study, this method has been chosen because it has a number of advantages a combination of group and individual work. Firstly, both full-time and part-time work with experts through questionnaires is possible, which is important given the remoteness of the studied territories. Secondly, the peculiarities of the Delphi survey allow minimizing the mutual influence of experts' opinions on each other-each expert individually works with the questionnaire; the information obtained in this way is integrated and gives an opportunity to get the most complete picture taking into account different positions on the topic under study.

\section{Discussion}

Discussions on the traditional economy of the indigenous peoples inevitably affect the protection of the way of life of the indigenous population as a whole. The peculiarity of the traditional way of life of the indigenous peoples is an inextricable link with nature, which indicates the need to protect the habitat that is the habitat of plants and animals, which are renewable resources necessary for the development of traditional forms of economic management. Reindeer breeding is the main type of traditional farming in the territory of the Evenkiysky Municipal District of the Krasnoyarsk Territory. Currently, there is an upswing in development in this area. The created municipal households provide an opportunity for representatives of the indigenous peoples to combine traditionalism and modernization in the economic sphere.

The traditional way of life of the indigenous small-numbered peoples of the North is a unique synthesis of the natural landscape, plants, animals and inhabitants of this land. The basis of interaction between a human and nature is a special worldview implying a vibrant attitude to the surrounding natural space and understanding of its place in it. In this case, the habitat is perceived as sacred, which forms a careful respect for the land of ancestors and its preservation for descendants. On this basis, a special system of prohibitions regulating consumption of natural resources is created, which allows preserving their self-reproduction.

The beginning of the $20^{\text {th }}$ century is a difficult period for the indigenous peoples of the North. The reforms initiated by the Soviet government collectivization and violent interference in the economic system, have caused the oblivion of traditional forms of economic management, many peoples turned out to be on the verge of extinction due to assimilation. At the dawn of the Soviet era, the attitude toward the indigenous small-numbered peoples has changed: they have actually been levelled to socially unprotected categories of citizens, the state subsidies have been paid, which also negatively affected traditional forms of economic management. By the 1990's of the $20^{\text {th }}$ century, the common instability in the economic and social sphere in the postSoviet territory contributed to the degradation of reindeer herding, the main traditional occupation of the indigenous people in Evenkia.

Nevertheless, at present reindeer herding is revived and shows positive results. An example is the reindeer herding of the Surinda village. Reindeer herding is not just a form of farming, it is part of the worldview, a way of life, without which there cannot be a full-fledged existence of the Evenki ethnos. According to an Evenki proverb, "no deer - no Evenk". Development of reindeer herding is a result of the activities of the Gaiulskii brothers, the descendants of the famous Evenk clan of reindeer herders. They found a reindeer breeding farm "Surindinskii" in 2002 .

Based on the information obtained during the interviews of the employees of the 
"Surindinskii" experimental production farm who work in reindeer herding teams moving along with deer throughout the Evenki taiga, it is possible to form a common position on the idea of the influence of climatic conditions on the traditional economy. The interviewees note that the territory of the Evenkiysky Municipal District is experiencing active anthropogenic and technogenic interference, which cannot but affect the life of the indigenous peoples. The reindeer herders emphasize the importance of natural climatic conditions for the successful development of reindeer herding, and express concerns about the interference of industrialists that violates the taiga ecosystem and infringes the traditional ways of deer movement across the taiga, which negatively affects the development of reindeer herding. While, for example, introducing the use of technical means of transportation (snowmobiles, etc.) during hunting or following the reindeer herd into the practice of traditional forms of economic management, the reindeer herders themselves have a minimal negative impact on ecology of the territories, since they are guided by the traditional principles of attitude to nature proclaiming a careful attitude and ensuring the restoration of resources taken from nature.

Many experts give a positive answer to the question on the connection between climate changes and economic development. Nevertheless, no unambiguous answer and assessment of changes have been given so far: these changes have a positive or negative impact. The question raises a lot of discussions that have not come to any consensus yet. And if for most Russian cities and settlements with developed production enterprises these issues are more or less settled, then for the settlements located at a considerable distance from the regional centres, they are only beginning to be comprehended and formalized in any scenarios.
Based on the results obtained using the Delphi survey method, a scenario of the most probable trends and prospects in the issue of climate changes and transformations in the traditional economy of the indigenous smallnumbered peoples of the North living in the Evenkiysky Municipal District (Krasnoyarsk Territory) by 2030 has been developed.

The basic provisions of the most probable scenario in the issue of climate change and transformation in the economy of the indigenous small-numbered peoples of the North (hereinafter referred to as the ISPN) living in the Evenkiysky Municipal District are found as a result of an analysis of two large questionnaires in 2010. The participants were the experts, whose authority in the study of the Arctic region and peoples living in this territory of ethnic groups, is beyond doubt. The scientific works of several researchers are devoted to the description of the effectiveness of this method (Kukushkina, 2007, Sokolov, 2007, Semenova, 2010). Also a few in-depth interviews have been conducted with a number of experts in the Delphi survey.

The obtained results of the questionnaires and interviews with experts demonstrate the ambiguity of perception of the issues of environmental change and the traditional economy of the ISPN. Some experts in Delphi survey tend to believe that the topic of climate change and its impact on people's lives and work is greatly exaggerated, and because of this Evenkia cannot develop adequately. For example, such vision throws into question the construction of the Evenki hydroelectric power station, where environmentalists and some of the local population do not allow the construction of an important facility indicating its dangerous, destructive potential for nature. The experts are sure that an unjustified fear for nature deprives the ISPN of jobs and a number of positive transformations in the region and, 
thereby, undermines the possibility of developing regional economy.

Most experts are inclined to see the future aggravation of climate changes and changes in traditional forms of economic management of the Evenks. They predict the intensive development of the territory of the Evenkiysky Municipal District in the coming years, which will adversely affect the development of the traditional economy. In their opinion, traditional works such as reindeer herding, hunting, fishing, gathering berries and mushrooms, etc. will remain, but the number of people involved in them will decrease. This will happen for a number of reasons, where one of the main reasons will be climate changes that cause a whole series of other interrelated problems.

The climate of the Evenkiysky Municipal District can be described as strongly continental, severe. The temperature can drop to $-67^{\circ} \mathrm{C}$ even in large towns, such as Tura. Frosts last for most of the year, about 240-275 days. Therefore, this territory belongs to the Far North.

Previously, the "cold climate" was perceived as natural protection of ethnic groups and their distinctive culture in the designated territory. Thanks to the cold, Evenkia has been reluctantly developed, and the Evenks preserved the foundations of their economic activities in their original form. Today, the Arctic issue is very urgent. The territory is considered as a zone of economic opportunities, a "tasty morsel" for large gas and oil companies. The work on finding, extracting and processing of resources is in full swing and there are a number of projects related to the development of this municipal district. Therefore, the climate system, the cold are now perceived differently creating more problems for the local population.

At the same time, the climate influences several important indices of life of the ISPN. Health, for example. Due to severe climatic conditions, the population has frequent ARD, cardiovascular diseases, joint diseases, etc. In addition to physical ailments, there are also psychological problems. Stresses, depressions are drowned by alcohol, to which the Evenks have no resistance. The experts point to greater likelihood of deteriorating demographic situation, strengthening depopulation and increasing the importance of socio-economic factors in the demographic development of the Evenks.

Serious problems are seen in the transport access of areas of compact residence of the ethnic communities of the Evenkiysky Municipal District, in their accessibility to healthcare and education facilities. These problems are not new and have been the first in the list of things that need to be solved for a long time. According to the experts, the same level of medical support and education provided for the ISPN will remain in the coming years: there are medical centres and schools, but they are not always staffed with the necessary staff and materials. There are positive shifts, of course. Thus, in Evenkia, the number of taiga primary schools gradually increases, allowing children to keep in touch with their parents who are staying in nomad camps all year round, to join in the way of life and culture of their people. However, such practices require a lot of costs and are ineffective in the first place, since the number of students does not often exceed a dozen.

The problems are observed in the construction of new housing. The houses are getting dilapidated, and there are very few new buildings. The grown up children are forced to live with their parents not being able to move to another house. Many of them are thinking about moving to other settlements, to somewhere with a better climate and more comfortable housing.

A poorly developed social infrastructure does not contribute to the improvement and development of the territories of compact settlement of the Evenks. The material base is 
obsolete and dilapidated, since it was created in the years of the Soviet Union and had to serve the needs of the state farms. Only a small reequipment of obsolete equipment is observed. But this is not enough. The possibility of creating a material base for social adaptation of the indigenous small-numbered peoples of the North in the new conditions when combining a traditional lifestyle with modern technologies is now under a big question.

Social development directly affects the indicators of physical health of ethnic groups, the level of their education. Many residents of the settlements of the Evenkiysky Municipal District have primary or incomplete secondary education. There is a lack of highly qualified specialists with higher education here.

All this affects the fact that in the North of the Krasnoyarsk Territory there is a high level of unemployment. The main source of subsistence for those who do not work in the budgetary sphere is seasonal work, social benefits and pensions of elderly relatives. Seasonal work is under threat already, and soon there probably will be introduction of norms that will regulate hunting and fishing even more rigidly. Hence, the most probable forecast - a significant increase in the number of alcoholics and drug addicts among the representatives of the Evenki ethnic group who are trying to "escape" from the hardships of life and poverty.

For the experts the future of Evenkia is not entirely positive, critical situations are possible. The most likely risks in the development of the northern areas of the Krasnoyarsk Territory, where the ISPN live, are:

1. The territories of compact settlement of the ISPN will become a space for competition between different "developing" subjects, resourceproducing companies. This will negatively affect their socio-economic development. Some experts noted that the industrial development of the North would come into sharp contradiction with the traditional way of life of the indigenous population. The consequences of the companies' activities will be the deterioration of the ecological situation in the territory, which will lead to reduction in the range of economic activities of the Evenks as economically and morally uncompetitive. Intensive development of the field work is not expected, since in many northern villages there is no system for processing products and merchandising. Here, the products of traditional farming are rarely sold, in small quantities and at extremely low prices. This makes the ISPN uncompetitive. The reindeer pastures and hunting lands will be reduced because of the development of the North by industrial companies, and fish will also be lost in the part of rivers and reservoirs used for traditional fisheries. Therefore, it will be much harder to survive, let alone managing your own business.

2. There are opportunities to attract representatives of the ISPN to the activities of large industrial companies, but there is high probability that they will act as service staff (for example, provide food for shift workers) without having the opportunity to occupy higher positions and have decent salary. Such a scenario can lead to a spiritual crisis of the ISPN.

It would seem that in the economy of northern territories, where representatives of the ISPN live, there is a hidden resource - small and medium business, that could improve the peoples' lives and spiritually encourage them, but it will remain unclaimed in the near future.

An interview with Ekaterina A. Sinkevich, a head of the Department for Protection of the Indigenous Environment of the Ministry for Affairs of the North and Support of the Indigenous Small-numbered Peoples of the Krasnoyarsk Territory, and a representative of the Evenki ethnos, affirmed the opinion of the majority. Ekaterina is sure that the above problems become 
a strong obstacle to the involvement of ethnic groups in the development projects. Accordingly, in order to change the likely scenario to the more desired for the representatives of the ISPN, it is necessary to introduce a strategy developed by the Chair for Cultural Studies of the Institute of the Humanities of SibFU. In this strategy, the intensive development of the North of the Krasnoyarsk Territory cannot occur without the representatives of the ISPN - unique populations that enrich the genotype and need careful treatment and preservation. Territories, on which the peoples live, are part of the Territory, part of history, part of the future state. It must be remembered that without preserving the forms of the traditional way of life and economic management, the ISPN may disappear as ethnoses, which cannot be tolerated in any way. The ethnoses can only be saved by simultaneous preservation of traditional industry (reindeer herding, fishing, hunting, dressing of hides, gathering of wild plants, etc.) and their modernization.

It is economic and labour activity that determines the prospects for the further existence of the Evenks in the territory of the Krasnoyarsk Territory, therefore, for positive changes in this area, it is necessary: firstly, to make adjustments at the level of political documents; secondly, to change the social infrastructure and, thirdly, to change an image of the future in the minds of the representatives of the ISPN themselves.

A place of the ISPNin the strategyofindustrial development of the region. Today, the regional policy related to the development of the northern territories is aimed at the industrial development of resources. In this matter, financial companies and industrial groups do not make contact with the local population and do not provide them with jobs or training in the fields where the personnel are in demand. Consequently, for the effective development of the ISPN, the understanding of the role of northern peoples in these processes should be changed - not superfluous, but necessary. And it is necessary to move from the setting "The North should be developed" to the setting "The North should be developed, but only taking into account ecological and cultural factors".

Changes for the better in cooperation with the government, financial and industrial groups and the indigenous peoples of the North can give such a phenomenon as "co-management". Or in other words - the resource management strategies formed as a result of coordinated relations between the authorities, representatives of financial and industrial groups, public and environmental organizations and the indigenous peoples.

The indicated mechanism presupposes the division of powers and responsibilities between the interacting parties. It has a wide range of forms of participation of the interaction parties. However, its basis will always be a principle of direct involvement of the aboriginal population in the solution of any issue concerning the development of territories of their residence. The indigenous peoples have the right to take part in all stages of industrial development, to control this process, and also to realize their interests and receive economic benefits in this process.

Financial independence of the ISPN. Most experts note the lack of workplaces, on which the ISPN would be employed, low wages. As a result, at the moment, a huge number of the population of working age in the northern territories does not want to work and simply lives on subsidies, drinking and degrading. Young people leave for larger settlements or larger cities. Accordingly, in the rural settlements of the North there is an extremely low percentage of people - workers in the budgetary sphere and those for whom the traditional way of life is life itself. At the same time, the ISPN have real prospects for existence, development in the environment of industrial and post-industrial societies, and for this it is 
necessary to transform the traditional forms of employment into market relations, to make business out of the field industry.

A positive scenario is built on the fact that reindeer herding remains the foundation that preserves and develops traditional industries. Its concentration should be increased, so that it is possible to provide employment for part of the able-bodied population. Reindeer herding should bring from $50 \%$ and more money income to the northern villages. The development of reindeer herding, the build-up of forces will meet the need for meat, hides, etc. Reindeer herding should develop in the private sector.

According to the experts, conservation of reindeer herding and the development of this industry can become the basis that will lead the indigenous peoples to self-sufficiency and economic independence from the state. Moreover, employment by reindeer herding will help preserve the language, traditions, culture and ethnic groups in general.

In a positive scenario the traditional industries and traditional spheres of economic management have development prospects both taking into account only the human factor, the change of documents, and by introducing new technologies into the way of the settled life of the ISPN. On the basis of public-private partnershipparticipation with the proper organization of nature management, there is a great opportunity to develop employment of the indigenous peoples, which will bring real income and will become the basis of their social self-development. That is, an integrated approach to the socially oriented development of the sphere of employment of the indigenous people should be developed and implemented, so that their work activity is determined by their culture, way of life, etc. The integrated approach presupposes cooperation of the indigenous communities with the state authorities, which coordinates the development of northern territories, private business, public organizations and scientific institutions.

Self-government of communities as a way of managing northern business. The local selfgovernment of communities should be developed, which will establish clear work with other organizations. It is the communities that part of the powers will be transferred to, it is here where a revenue base will be formed, which will allow the communities to solve their problems on their own.

A system of trading stations can be created, in which the development of traditional industries of the ISPN will be clearly reflected. The system of trading stations can substantially improve the economic development of the northern territories.

Of course, the effective development of the economy of the northern territories, where the indigenous people live, should be accompanied by the entry of traditional farm products into the regional and Russian markets. A sales system must be implemented. The system of trading stations can take over the functions of harvesting, storing, processing, transporting and marketing the products that the representatives of the indigenous people will produce. Expansion of the trading stations will allow developing traditional industries.

\section{Conclusion}

On the basis of the analysis, a number of conclusions can be drawn.

Representatives of the indigenous peoples skilled workers involved in the traditional economic activities, note the unconditional connection between climatic conditions and the possibility to be effectively engaged in traditional forms of economic management - the main thing for the residents of the Evenkiysky Municipal District is reindeer herding. Respondents express their apprehensions about the situation resulting 
from the active industrial development of the North, which entails certain changes in the natural landscape of the Evenki territory, and also call technogenic intervention to be an activity potentially capable of influencing the change in climatic conditions.

At the same time, as the experts' responses show, in the near future there is a great risk of imbalance in the development of traditional indigenous peoples' industries and their social development, this entails large expenditures of budgetary forces and time for solving private problems, but does not change the situation as a whole. After all, the task of developing traditional farming in rural areas of the indigenous people's settlement is complex. Each private problem is interconnected with a number of other problems. Therefore, the decision of only a couple of issues will not substantially change the municipal district, and it will not make it promising for the development of the northern business, etc. In modern conditions, for sustainable development of traditional industries (the social development of northern ethnic groups depends on), their state support is needed through the renewal of relevant institutions with the participation of the ISPN. For this, it is necessary to develop communities that will be focused on independent and socially oriented development.

However, we should not forget that this is only a scenario of probabilities, which may or may not come true. Compared to other northern territories, climate changes and changes in the traditional economy in the Evenkiysky Municipal District cannot be called catastrophic. At least for the reason that in this territory, on the one hand, the processes that entail the waste of the "basic human capital" are neutralized, on the other hand, the work is being carried out to preserve and maintain the traditional way of life of the indigenous small-numbered peoples. The study of some villages (Surinda, Essey) makes it possible to observe the revival of traditions and language among the Evenks, as well as a strong desire for the revival and development of traditional industries (reindeer herding), which, in turn, indicates that the Evenk people definitely have future.

\section{References}

Adger, W.N. (2013). Cultural dimensions of climate change impacts and adaptation. In Nature Climate Change, 3 (2), 112-117.

Amosov, A.E., Bakhova, N.A., Bokova, V.I. (2012). Korennye malochislennye narody Severa $i$ Sibiri v usloviiakh global'nykh transformatsii (na materiale Krasnoiarskogo kraia). Kontseptual'nye i metodologicheskie osnovy issledovaniia. Etnokul'turnaia dinamika korennykh malochislennykh narodov Krasnoiarskogo kraia [Indigenous small-numbered peoples of the North and Siberia under conditions of global transformations (based on the material of the Krasnoyarsk Territory). Part 1. Conceptual and methodological foundations of the research. Ethno-cultural dynamics of the indigenous small-numbered peoples of the Krasnoyarsk Territory]. Krasnoyarsk: Publishing house of Siberian Federal University.

Arkticheskoe prostranstvo Rossii v XXI veke: factory razvitiia, organizatsiia i upravlenie [Arctic space of Russia in the $21^{\text {st }}$ century: development factors, organization and management]. (2016). SaintPetersburg: Publishing house "Nauka", 1040.

Avdeeva,Iu.N.,Libakova, N.M.(2015). Mezhdunarodnyepraktikisotsiokul'turnogoproektirovaniia po otnosheniiu k korennym malochislennym narodam Severa, Sibiri i Dal'nego Vostoka [International practices of socio-cultural design in relation to the indigenous minorities of the North, Siberia and 
the Far East]. In Sotsiodinamika [Socio-dynamics], 10, 10-38. DOI: 10.7256 / 2409-7144.2015.10.1643. URL: http://e-notabene.ru/pr/article_16430.html

Balatskii, E.V. (2010). Tekhnologii predvideniia budushchego: ot slozhnogo $\mathrm{k}$ prostomu [Technologies for foreseeing the future: from the complex to the simple]. In Zhurnal ob investitsionnykh vozmozhnostiakh Rossii "Kapital strany” [Journal of Investment Opportunities in Russia "Capital of the Country"], available at: http://www.kapital-rus.ru/articles/article/64

Berkes F., Jolly, D. (2002). Adapting to climate change: social-ecological resilience in a Canadian western Arctic community. In Conservation ecology, 5 (2), 18.

Blokov, K.B., Krasovskaia, T.M., Iamskaia, A.N. (2002). Etnokul'turnye aspekty prirodopol'zovaniia Arkticheskogo regiona Rossii [Ethno-cultural aspects of nature management in the Arctic region of Russia]. In Geografiia i prirodnye resursy [Geography and Natural Resources], 4, 23-29.

Bukova, M.I. (2016). Osobennosti etnokul'turnogo samosoznaniia etnicheskoi gruppy chulymtsev, kompaktno prozhivaiyshchikh na territorii derevni Pasechnoe Tiukhtetskogo raiona Krasnoiarskogo kraia (Tsentral'naia Sibir') [Peculiarities of ethno-cultural self-identification of the ethnic group Chulyms who compactly reside in the Pasechnoe village of the Tiukhtetskii district of the Krasnoyarsk Territory (Central Siberia)]. In Sotsiodinamika [Socio-dynamics], 4, 41-51. DOI: 10.7256 / 24097144.2016.4.18414. Available at: http://e-notabene.ru/pr/article_18414.html

Ford, J.D., Smit, B., Wandel, J. (2006). Vulnerability to climate change in the Arctic: a case study from Arctic Bay, Canada. In Global Environmental Change, 16 (2), 145-160.

Furgal, C., Seguin, J. (2006). Climate change, health, and vulnerability in Canadian northern Aboriginal communities. In Environmental health perspectives, 1964-1970.

Intergovernmental Panel on Climate Change. Climate Change 2014-Impacts, Adaptation and Vulnerability: Regional Aspects. (2014). Cambridge University Press.

Israel', Iu.A. (2001). Izmeneniia global'nogo klimata. Rol' antropogennykh vozdeistvii [Changes in the global climate. The role of anthropogenic influences]. In Meteorologiia i gidrologiia [Meteorology and Hydrology], 5, 5-22.

Katsov, V.M., Porfir'ev, B.N. (2012). Klimaticheskie izmeneniia v Arktike: posledstviia dlia okruzhaiushchei sredy i ekonomiki [Climate changes in the Arctic Region: implications for the environment and economy]. In Arktika: ekologiia i ekonomika [Arctic Region: ecology and economics], 2, 6 .

Kirko, V.I., Zakharova, K.N. (2013). Traditsionnaia khoziaistvennaia deiatel'nost' etnosokhraniaiushchii obraz zhizni [Traditional economic activity - an ethno-preserving way of life]. In Arktika $i$ Sever [Arctic Region and the North], 12, 24-31.

Kirko, V.I., Keush, A.V. (2012). Vovlechenie korennykh malochislennykh narodov Severa v innovatsionnye protsessy [Involvement of the indigenous small-numbered peoples of the North in the innovation processes]. In Vestnik Krasnoiarskogo gosudarstvennogo agrarnogo universiteta [Bulletin of Krasnoyarsk State Agrarian University], 10, 233-237.

Kirko, V.I., Bukharov, A.V., Keush, A.V. (2010). Otsenka Innovatsionnogo Potentsiala Tipovykh Territorial'no-Administrativnykh Obrazovanii Krasnoiarskogo Kraia [Assessment of the Innovative Potential of the Model Territorial Administrative Entities of the Krasnoyarsk Territory]. In Innovatsii [Innovations], 12, 78-83. 
Kirko, V.I., Koptseva, N.P., Nevzorov, V.N., Nozdrenko, E.A., Slabukha, A.V. (2013). Mezhdistsiplinarnye Ekspeditsii - Effektivnyi Sposob Formirovaniia Komand Dlia Realizatsii Kompleksnykh Innovatsionnykh i Investitsionnykh Proektov [Interdisciplinary Expeditions - an Effective Method for Forming Teams for the Implementation of Integrated Innovative and Investment Projects]. In Arktika i Sever [Arctic Region and the North], 13, 4-13.

Kirko, V.I. (2015). Postsovetskie praktiki sokhraneniia etnokul'turnoi identichnosti korennykh narodov Severa i Sibiri v Krasnoiarskom krae Rossiiskoi Federatsii [Post-Soviet practices of preserving the ethno-cultural identity of the indigenous peoples of the North and Siberia in the Krasnoyarsk Territory of the Russian Federation]. In Sotsiodinamika [Socio-dynamics], 6, 113-133. DOI: 10.7256 / 2409-7144.2015.6.15607. Available at:: http://e-notabene.ru/pr/article_15607.html

Kistova, A.V., Sevruzhenko, N.S. (2016). Koreitsy v sovremennoi Rossii: rol' etnicheskikh men'shinstv [Koreans in modern Russia: the role of ethnic minorities]. In Sotsiodinamika [Sociodynamics], 3, 62-72. DOI: 10.7256 / 2409-7144.2016.3.18204. Available at:: http://e-notabene.ru/pr/ article_18204.html

Kondrat'ev, K.Ia. (2002). Izmenenie global'nogo klimata: real'nost', predpolozheniia i vymysel [Change in the global climate: reality, assumptions and fiction]. In Issledovanie Zemli iz kosmosa [Study of the Earth from Space], 1, 3-23.

Koptseva, N.P. (2013). K voprosu o sokhranenii i vosporizvodstve traditsionnoi kul'tury korennykh malochislennykh narodov Severa, Sibiri i Dal'nego Vostoka v Sibirskom federal'nom ogruge [On the issue of preservation and reproduction of the traditional culture of the indigenous small-numbered peoples of the North, Siberia and the Far East in the Siberian Federal District]. In Sotsiodinamika [Socio-dynamics], 12, 1-16.

Koptseva, N.P. (2014). K voprosu o gosudarstvennoi politike v oblasti sokhraneniia iazykov korennykh malochislennykh narodov Severa [On the issue of state policy in the field of preservation of the indigenous languages of the North]. In Arktika i Sever [Arctic Region and the North], 16, 34-39.

Koptseva, N. (2015). The current economic situation in Taymyr (the Siberian Arctic) and the prospects of indigenous peoples' traditional economy. Economic Annals-XXI, Ukraine, 9-10, 9597.

Koptseva, N.P., Kolesnik, M.A. (2016). Formirovanie Pozitivnoi Kul'turnoi Identichnosti Kak Faktor Natsional'noi Bezopasnosti Sovremennoi Rossii. Rezul'taty Assotsiativnogo Eksperimenta S Assotsiatom "russkoe" (na Materiale Issledovaniia Studencheskikh Grupp Sibirskogo Federal'nogo Universiteta) [Formation of Positive Cultural Identity As a Factor of National Security of Modern Russia. Results of the Associative Experiment with the "Russian" Associate (on the Material of the Student Groups Study of the Siberian Federal University)]. In Natsional'naia bezopasnost' / nota bene [National security / nota bene], 1, 129-148.

Koptseva, N.P., Zamaraeva, Yu.S., Kistova, A.V., Pimenova, N.N., Seredkina, N.N., Reznikova, K.V., Fil'ko, A. (2016a). Place Management: Decoding The Visual Image Of A Siberian City. In Journal of Applied Economic Sciences, 11 (6), 1144-1156.

Koptseva, N.P., Zamaraeva, Yu.S., Pimenova, N.N., Kistova, A.V., Seredkina, N.N., Reznikova, K.V. (2016b). Regional Peculiarities In Modernization Processes Within The Territories Of Central Siberia. International Review of Management and Marketing, 6 (4), 857-865. 
Kotliakov, V.M. (2001). Global'nye izmeneniia klimata: antropogennoe vliianie ili estestvennye variatsii? [Global climate changes: anthropogenic impact or natural variations?] In Ekologiia i zhizn' [Ecology and Life], 1, 44-47.

Krasovskaia, T.M. (2006). Novye funktsii traditsionnogo prirodopol'zovaniia na Severe Rossii $\mathrm{v}$ usloviiakh rynochnoi ekonomiki [New functions of traditional nature management in the North of Russia in the market economy]. In Vestnik Moskovskogo universiteta [Bulletin of Moscow University], $5,22-27$.

Kukushkina, S.N. (2007). Metod Del'fi v Forsait-proektakh [The Delphi survey method in Foresight projects]. In Forsait. Gosudarstvennyi universitet - vysshaia shkola ekonomiki [Foresight. State University - Higher School of Economics], 1, 68-73.

Libakova, N.M. (2015). Upravlenie Zdravookhraneniem Dlia Korennykh Narodov Tsentral'noi Sibiri (na Materiale Analiza Krasnoiarskogo Kraia [Health Management for the Indigenous Peoples of Central Siberia (on the Material of the Analysis of the Krasnoyarsk Territory)]. In Trendy $i$ Upravlenie [Trends and Management], 4, 380-394.

Libakova, N.M., Sertakova, E.A., Kolesnik, M.A., Sitnikova, A.A., Il’beikina, M.I. (2016). Sovremennye strategii sotsial'nogo pozitsionirovaniia sibirskikh regionov [Modern strategies for social positioning of Siberian regions]. In Sotsiodinamika [Socio-dynamics], 1, 162-189. DOI: 10.7256 / 2409-7144.2016.1.17420. Available at: http://e-notabene.ru/pr/article_17420.html

Libakova, N.M., Sertakova, E.A. (2014). Kul'turologicheskoe issledovanie korennykh malochislennykh narodov Severa Krasnoiarskogo kraia: rezul'taty ekspertnogo interv'iu [Culturological research of the indigenous small-numbered peoples of the North of the Krasnoyarsk Territory: results of an expert interview]. In Sovremennye problemy nauki i obrazovaniia [Modern problems of science and education], 4.

Loginov, V. (2012). Radiatsionnye factory i dokazatel'naia baza sovremennykh izmenenii klimata [Radiation factors and evidence base of modern climate changes]. Minsk, Bularuiskaia Navuka, 266 p.

Lopulenko, N.A. (2009). Narody Severa v usloviiakh global'nykh prirodno-klimaticheskikh izmenenii [Peoples of the North in conditions of global natural and climatic changes]. In Etnos $i$ sreda obitaniia [Ethnos and habitat], (1). Collection of ethnoecological research for the $85^{\text {th }}$ anniversary of V.I. Kozlov, 139-241.

Luzan, V.S. (2016). K voprosu o vliianii kel'turnoi politiki na sovremennye lokal'nye identichnosti [On the issue of the influence of cultural policy on modern local identities]. In Sotsiodinamika [Sociodynamics], 2, 47-66. DOI: 10.7256 / 2409-7144.2016.2.17733. Available at: http://e-notabene.ru/pr/ article_17733.html

Medvedkov, A.A. (2012). Kety: taezhnaia kul'tura i traditsionnoe khoziaistvo v sovremennykh sotsial'no-ekonomicheskikh i prirodno-klimaticheskikh usloviiakh [The Kets: taiga culture and traditional economy in modern socio-economic and natural climatic conditions]. In Regional'nye issledovaniia [Regional Studies], 4, 142-147.

Meleshko, V.P. (2004). Vozmozhnye antropogennye izmeneniia klimata Rossii v XXI veke: otsenki po ansambliu klimaticheskikh modelei [Possible anthropogenic climate changes in Russia in the $21^{\text {st }}$ century: assessments of climate models]. In Meteorologiia i gidrologiia [Meteorology and Hydrology], 4, 38-49. 
Moss, R.H. (2010). The next generation of scenarios for climate change research and assessment. In Nature, 463 (7282), 747-756.

Pearce, T. (2015). Inuit traditional ecological knowledge (TEK), subsistence hunting and adaptation to climate change in the Canadian Arctic. In Arctic, 233-245.

Pimenova, N.N. (2012). Problems of Education of Children of Indigenous Numbers of Siberia and the North in the Krasnoyarsk Territory, Innovations in Continuing Education, Russia, 5, 12-18.

Pimenova, N.N. (2014). Kul'turnoe nasledie korennykh malochislennykh narodov Krasnoiarskogo kraia i sovremennye kul'turnye praktiki [The cultural heritage of the indigenous small-numbered peoples of the Krasnoyarsk Territory and modern cultural practices]. In Chelovek i kul'tura [Human and Culture], 2, 28-66.

Pimenova, N.N. (2015). Korennye malochislennye narody sovremennoi situatsii: ob'em i soderzhanie poniatiia [The indigenous small-numbered peoples in the current situation: scope and content of the concept]. In Sotsiodinamika [Socio-dynamics], 1, 112-134.

Pimenova, N.N. (2016). Mechanisms of Socio-Cultural Changes in the Indigenous Peoples of Siberia and the North: the Concept of Cultural Injury of P. Shtompka. In Sotsiodinamika [Sociodynamics], Russia, 3, 37-45.

Popper, R. Keenan, M., Miles, I., Butter, M., Saintz de la Fuenta S. (2007). Global foresight outlook 2007. In EFMN, 66, available at: http://www.foresight-network.eu/files/reports/efmn mapping_2007.pdf

Reznikova, K.V. (2015a). Sokhranenie traditsionnykh iazykov korennykh malochislennykh narodov kak obespechenie osnovy kul'turnogo raznoobraziia regiona [Preservation of traditional languages of the indigenous small-numbered peoples as providing the basis for cultural diversity of the region]. In Sovremennye problemy nauki i obrazovaniia [Modern problems of science and education], 1-1.

Reznikova, K.V. (2015b). Etnichnost' kak kategoriia sotsial'nogo poznaniia [Ethnicity as a category of social cognition]. In Sotsiodinamika [Socio-dynamics], 1, 101-111. DOI: 10.7256 / 24097144.2015.1.14228. Available at: http://e-notabene.ru/pr/article_14228.html

Reznikova, K.V., Pimenova, N.N., Kistova, A.V., Seredkina, N.N., Zamaraeva, Iu.S. (2016). Upravlenie brendingom sibirskoi territorii v svete "novogo regionalizma" [Management of branding of Siberian territory in the light of the "new regionalism"]. In Sotsiodinamika [Socio-dynamics], 1, 137161. DOI: 10.7256 / 2409-7144.2016.1.17395. Available at: http://e-notabene.ru/pr/article_17395.html

Riedlinger, D., Berkes, F. (2001). Contributions of traditional knowledge to understanding climate change in the Canadian Arctic. In Polar Record, 37 (203), 315-328.

Semenova, A.A. (2010). Modern Practices of Foresight Research of the Future of SocialAnthropological Systems, Including Ethnical Cultural Populations. In Journal of Siberian Federal University. Humanities \& Social Sciences, 5 (3), 667-676

Seredkina, N.N. (2014). Etnicheskaia kartina mira v kontekste sovremennykh sotsial'nykh issledovanii [Ethnic picture of the world in the context of modern social studies]. In Sotsiodinamika [Socio-dynamics], 10, 26-59. DOI: 10.7256 / 2306-0158.2014.10.1344. Available at: http://e-notabene. $\mathrm{ru} / \mathrm{pr} /$ article_13441.html

Seredkina, N.N. (2016). Teoreticheskaia model' pozitivnoi etnicheskoi identichnosti i mekhanizmy ee formirovaniia [Theoretical model of positive ethnic identity and mechanisms of its formation]. In 
Sotsiodinamika [Socio-dynamics], 2, 37-46. DOI: 10.7256 / 2409-7144.2016.2.17690. available at: http://e-notabene.ru/pr/article_17690.html

Sertakova, E.A., Avdonina, E.Iu. (2016). Vynuzhdennaia migratsiia i ee otrazhenie v kinematograficheskom isskustve [Forced migration and its reflection in cinematographic art]. In Sotsiodinamika [Socio-dynamics], 2, 106-116. DOI: 10.7256 / 2409-7144.2016.2.17747. Available at: http://e-notabene.ru/pr/article_17747.html

Shishatsky, N.G., Kirko, V.I., Keush, A.V. (2012). Sotsial'no-ekonomicheskie Problemy Sozdaniia Territorii Traditsionnogo Prirodopol'zovaniia [Socio-economic Problems of Creating Territories of Traditional Nature Management]. In Arktika i Sever [Arctic Region and the North], 7, 178-184.

Sokolov, A.V. (2007). Metod kriticheskikh tekhnologii [The method of critical technologies]. In Forsait. Gosudarstvennyi universitet - vysshaia shkola ekonomiki [Foresight. State University Higher School of Economics], 4, 64-75.

Tishkov, A.A. (2011). Biograficheskie posledstviia prirodnykh i antropogennykh izmenenii klimata [Biogeographic effects of natural and anthropogenic climate changes]. In Uspekhi sovremennoi biologoo [Advances in modern biology], 131 (4), 356-366.

Zamaraeva, Iu.S. (2014). K voprosu o vozdeistvii global'nykh transformatsii na korennye narody Severa, kompaktno prozhivaiyshchikh v regionakh Rossiiskoi Federatsii [On the impact of global transformations on the indigenous peoples of the North that compactly reside in the regions of the Russian Federation]. In Mezhdunarodnyi zhurnal prikladnykh i fundamental'nykh issledovanii [International Journal of Applied and Fundamental Research], 5-1.

\title{
Влияние климатических условий
}

на традиционную экономику коренных

малочисленных народов, проживающих

в Эвенкийском муниципальном районе

(Красноярский край)

\author{
М.А. Колесник, Н.М. Либакова, \\ Е.А. Сертакова, Н.А. Сергеева \\ Сибирский федеральныий университет \\ Россия, 660041, Красноярск, пр. Свободньй, 79
}

Проблема климата на сегодняиний день является одной из самых актуальных и обсуждаемых в различных контекстах. В настоящей статье поднимается проблема взаимосвязи климатических условий и осуществления традищионных форм хозяйствования коренными жителями Эвенкийского муниципального района Красноярского края. На основе результатов полевых исследований, интервьюирования экспертов и применения метода Дельфи-опроса сделаны выводы о современном состоянии традиционной экономики коренных малочисленных народов Севера Красноярского края и влиянии на нее климатических условий, а также представлень прогнозы о перспективах развития традиционных форм хозяйствования (оленеводства, охоты, рыбной ловли, сбора дикоросов) с учетом влияния климатических условий и их динамики. 
Ключевые слова: традиционные формы хозяйствования, коренные малочисленные народы, климатические условия, Эвенкийский мунищипальный район, Красноярский край.

Исследование выполнено при финансовой поддержке Российского фонда фундаментальных исследований, Правительства Красноярского края, Красноярского краевого фонда поддержки научной и научно-технической деятельности в рамках научного проекта № 17-16-24601.

Научная специальность: 24.00.00 - культурология. 